This item was submitted to Loughborough's Research Repository by the author.

Items in Figshare are protected by copyright, with all rights reserved, unless otherwise indicated.

\title{
Country focus: France
}

PLEASE CITE THE PUBLISHED VERSION

http://dx.doi.org/10.1111/2041-9066.12071

\section{PUBLISHER}

Blackwell Publishing Wiley Online Library @ Political Studies Association

\section{VERSION}

AM (Accepted Manuscript)

\section{PUBLISHER STATEMENT}

This work is made available according to the conditions of the Creative Commons Attribution-NonCommercialNoDerivatives 4.0 International (CC BY-NC-ND 4.0) licence. Full details of this licence are available at: https://creativecommons.org/licenses/by-nc-nd/4.0/

\section{LICENCE}

CC BY-NC-ND 4.0

\section{REPOSITORY RECORD}

Drake, Helen. 2019. “Country Focus: France”. figshare. https://hdl.handle.net/2134/16470. 
Country Focus - France

Helen Drake, Loughborough University ${ }^{1}$

\section{Flawed democracy?}

For three years running, in 2011, 2012 and 2013, France has been branded a 'flawed' democracy by the Economist Intelligence Unit's Democracy Index. A key reason for the verdict is the 'erosion of sovereignty and democratic accountability associated with the effects of and responses to the euro zone crisis' (Economist Intelligence Unit, 2011). Addressing the urgency of economic recovery without losing its footing over the next two years is the French government's challenge, and in this article I explore the immediate and longer-term dimensions of this situation. The present difficulty for the French socialist government is to steer the economy habitually measured as the fifth largest in the world - towards the austere fiscal targets set in conjunction with the European Commission at a time of stubbornly high unemployment (the jobless figure is expected to remain over $10 \%$ by the end of 2015). The deal reached with the EU was to reduce the public deficit to $3 \%$ and the public debt to $60 \%$ of GDP in the same time frame. All indications are that the deficit will not be brought under control this far and this fast and, since the current rules of EU governance are stringent and intrusive, this failure will be very public, and can be expected to further weaken political support for austerity politics at home.

\section{No confidence}

This ever diminishing autonomy in fiscal affairs already cost the French Prime Minister Manuel Valls his first government. In August 2014, after only 147 days in office and in response to a very public rebuke by his Minister for the Economy and Productive Recovery, Arnaud Montebourg, over the austerity measures in train, Valls sacked Montebourg and other detractors from the cabinet, and put a newlyassembled government to a vote of confidence in the French National Assembly on 16 September 2014. The purpose of the manoeuvre was to establish sufficient

\footnotetext{
1 Helen Drake is Professor of French and European Studies at Loughborough University and Chair of UACES (University Association for Contemporary European Studies) - the UK's academic association for the study of Europe and the European Union. Recent publications include Contemporary France (Palgrave, 2011).
} 
political legitimacy for the government to make its next round of cuts to public expenditure and subsequently pass its budget for 2015. The government's victory was slender (269 in favour and 244 against) and more Socialist Party deputies abstained than in April 2014 when Manuel Valls first took office as Prime Minister and put his government's confidence to the parliamentary vote. The ruling French Socialist Party has thus shown itself to be divided in its approach to economic policy at a time when the economy remains the number one preoccupation of French voters. These voters have themselves contributed to the cracks in party unity by declining to support the Socialist government on three separate occasions since the party won both the presidency and the legislature in May 2012.

In March 2013 the municipal elections were a serious defeat for the government. Abstention was higher than usual (nearly 40\%), the party lost control of 150 towns and cities, the opposition UMP (Union pour un mouvement populaire) and allies won a $62 \%$ majority and the Front national consolidated its gains from the previous local elections in 2008. The magnitude of this defeat prompted President Hollande to replace his Prime Minister Jean-Marc Ayrault with Manuel Valls, who has since proven himself unafraid to take the leading role more habitually associated with the incumbent of the Elysée. The municipal elections return councillors to every single one of France's basic unit of governance, the commune (France still has 36,000 of these), and in so doing constitute the electoral college that elect the upper house of Parliament, the Senate. It was therefore no surprise when in September 2014 the elections to replace half the senatorial body also returned a majority for the opposition, and in so doing restored a right-wing majority to that House that had only been briefly troubled by three years of Socialist dominance (from 2011-2014) in all its history. Notably, the senatorial elections for the first time ever returned two National Front members, reflecting the party's victory at the local level earlier in the year (and at the 2012 legislative elections the party had won two seats in the National Assembly, following a record $6.5 \mathrm{~m}$ votes in the first round of the presidential elections of the same year). In between these two votes came the elections to the European Parliament in May 2014. Fought entirely on proportional 
representation, the result was a notable victory for the National Front which with 4.7 million votes cast won 24 seats in the Strasbourg chamber, its largest number yet.

\section{Holding back the tide}

The Front national was formed in the early 1970s, came to prominence a decade later under the leadership of its founder, Jean-Marie le Pen, and since 2011 has seen its biggest successes with le Pen's daughter, Marine le Pen, at the helm. Explanations for its prominence in contemporary France lie in part in the political culture of the country. France's historically multiparty political system is perennially subject to centrifugal forces which place traditional allegiances and affiliations under strain. Conventions of personalised political leadership exacerbate these tensions and the Front national has consistently tapped these populist veins. It has also capitalised on unpopular presidents to challenge the institutions of the Fifth French Republic as well as policies towards the EU and immigration. The presidential office, the pinnacle of governance in the Fifth Republic, was designed to be ambitious for the nation, setting the cap for a seven-year term on the basis of an absolute majority of the popular vote. In its present, five-year form it is doomed to raise expectations in keeping with the traditions of the office, but routinely fail to meet them. Why is this? First, the presidential office is increasingly brought into disrepute in a postdeferential age where the traditional privacy of French public figures can no longer be realistically upheld (the exposure of President Hollande's human frailties in book form-Merci pour ce moment - by his former partner Valérie Trierweiler is a trivial example of such developments; as were former president Sarkozy's very public love lives). Second, the incumbents of the Elysée Palace have been revealed to be worldly to the point of corrupt. Former President Jacques Chirac (1995-2002) was found guilty of financial wrong-doing dating back to the years when he was Mayor of Paris; and Nicolas Sarkozy, president between 2007-2012 has yet to escape numerous different allegations of misconduct which include the financing of his 2012 election campaign. In this light, Sarkozy's decision to return to politics in time to fight the 2017 presidential elections can be seen to be as instrumental as it is populist: he has promised to build a 'mass movement' of political support; and, in heroic leadership style, claims he has 'no choice' but to return to solve the country's problems. 
Third, and more substantially, the French presidency is constrained by its 360 degrees of interdependence: there are more checks and balances in whichever direction the President cares to look. Across the Seine in the seat of government at Matignon, Prime Minister Valls is over twice as popular as President Hollande whose ratings in September 2014 were a dismal 13\% . Looking eastwards to Brussels, the ability of the President to deliver his election promises is complicated by the fiscal and other rules of the EU. And from all points of the compass, rules and regulations of international governance reach deep into traditionally sovereign political fields including human rights legislation and foreign policy. This is an interdependence which defines France as a country open to forces of many kinds, and in French political language that openness is subsumed in the fear-mongering term of $l a$ mondialisation, or globalisation. In more recent years that term has itself come to operate as a proxy for other more insidious fears, notably of the imagined impact of France's large Muslim population on the cohesion of the nation. For the Front national and other figures - including Nicolas Sarkozy - France's cultural heterogeneity is constructed as a potential threat not only to French identity, but to the physical security of the nation. The domestic ramifications of France's involvement in fighting Islamic extremism abroad, and of its foreign interventions full stop (most recently in Mali and in the Central African Republic; and it was willing, in 2013, to also target Syria) are real. Killers of French tourist Hervé Gourdel, beheaded in September 2014 by extremists in Algeria, directly linked his death to French participation alongside the US in military action against the Islamic State in Iraq. The French response to date has been to continue determinedly in what those it targets calls its 'crusade' against Islamic State, while collaborating with its allies to deter French citizens from fighting alongside its enemies (in Syria, for example). In this climate, other progressive developments in French society have met with significant opposition that explicitly equates them to a threat to the integrity of French identity. The government passed its bill to legalise same sex marriage (le mariage pour tous) and adoption in May 2013 and in the process unleashed a sustained backlash: la manif pour tous ('all out against': an umbrella group of groups formed in protest at these developments). This campaign has subsequently turned 
its attention to reproductive rights including surrogacy and medically assisted procreation and, in particular, the extension of these rights beyond the traditional heterosexual couple + children family unit. These are aspects of society where those fighting for their rights can frame their claims in terms of international legal norms, which makes the developments all the more insidious in the eyes of their detractors.

\section{'Made in France'}

Contemporary France in 2014 is far more internationalised than even ten years ago, and the momentum is probably unstoppable. The English language is a knowing badge of global identity in France's urban environments [USE IMAGE 'MADE IN FRANCE']. French electro-pop duo Daft Punk's English-language album Random Access Memories won five Grammy awards in 2014. French Prime Minister Manuel Valls, in London in October 2014 declared admiringly in the face of 'French-bashing' from leading UK industrialists that 'my government is pro-business' too, citing his determination to lift restrictions on Sunday trading to induce Chinese tourists to shop in Paris - not London - on both days of the weekend; and the 'Responsibility Pact' introduced by the government in January 2014 is designed to structure this pro-business emphasis in a country where by many measures, tax and regulatory burdens on enterprise are still crushing. The Franco-American friendship is as important as ever to France. The challenge for the country thus seems to be how to respond appropriately to the choices that still remain within this internationalist frame. A recent report commissioned by the government and written by economist Jean Pisani-Ferry, head of the Prime Minister's policy planning unit, is instructive in this regard (Pisani-Ferry, 2014). Drawing explicitly on scholarly literature and policy lessons from France's international allies and comparators, first and foremost the USA and the UK, the report offers a diagnosis of the state of France in 2014 and sets targets for 2025 that are measurable and expressed in comparative terms: by 2025 , for example, France should aim to achieve a $70 \%$ turnout at legislative elections; to be in the top third of European countries for non-discrimination on ethnic grounds; have 10 universities in the world rankings; to double the number of French students who go abroad to study; and almost double the number of international students in France to nearly 500,000 . 
One of the most striking features of this analysis is the enthusiasm with which it embraces France's options for more openness and international success, and cautions against painting overly-pessimistic scenarios of France's future. It is true that intellectual blinkers inside and outside France have contributed to what PisaniFerry has called 'le catastrophisme' (2014: 53); or what others might think of as le déclinisme. These are popular narratives that portray contemporary France as engaged on a slow path to decline and decay. This picture is defied by anecdotal and empirical evidence of a country in movement, and for Pisani-Ferry the slide is not fatal. But stopping the rot means fixing the flaws in French democracy, and holding the policy-making gaze firmly on the longer-term.

\section{References and further readings}

Economist Intelligence Unit (2011) 'Democracy Index 2011: Democracy under Stress', accessed at

https://www.eiu.com/public/topical_report.aspx?campaignid=Democracylndex2011 on 7 July 2012.

Pisani-Ferry, J. (2014) 'Quelle France dans dix ans? Les chantiers de la décennie' (Paris, France stratégie http://francedans10ans.fr/\#/).

\section{Further reading:}

Cole, Meunier, S. and Tiberj, V. (eds.) (2013) Developments in French Politics 5 (Palgrave)

H. Drake (2011) Contemporary France (Palgrave)

N. Hewlett (2011) The Sarkozy Phenomenon (Imprint Academic)

Parliamentary Affairs (2013) 66, 1 (January): Special Issue - French Presidential and Parliamentary Elections 2012.

French Politics. Special collection of articles exploring the presidency of Nicolas Sarkozy http://www.palgrave-journals.com/fp/collections/sarkozy collection.html 
